\title{
Prevalence and risk factors associated with ectoparasite infestation of buffaloes in an Amazonian ecosystem
}

Helder Ribeiro Batista ${ }^{1}$, Cristiane Sarturi ${ }^{1}$, Felipe Nascimento Stelmachtchuk', Daniel Rocha Oliveira', Adriana Caroprezo Morini ${ }^{1}$, Solange Maria Gennari², Arlei Marcili²,3, Fernanda Aparecida Nieri Bastos ${ }^{4}$, Lauro Euclides Soares Barata ${ }^{4}$ and Antonio Humberto Hamad Minervino ${ }^{*^{*}}$ (i)

\begin{abstract}
Background: The water buffalo (Bubalus bubalis) is well adapted in some regions of the Amazon. Of all Brazilian states, Pará contains the largest number of this species, with 510,000 animals, approximately $38 \%$ of the Brazilian buffaloes. Despite the socioeconomic importance of bubaline farming in the northern region, little is known about the prevalence of ectoparasites that affect buffalo herds. This study aimed to identify the species of buffalo ectoparasites in the municipality of Santarém, Pará, and to determine possible risk factors related to ectoparasitic infestation. A cross-sectional study was conducted by sampling 60 rural properties and 621 buffaloes for ectoparasites. When present, ectoparasites were collected for subsequent identification.

Results: Of all the animals sampled, 18.5\% (115/621) had ectoparasites, 7.8\% (49/621) had ticks from the species Rhipicephalus (Boophilus) microplus and Amblyomma cajennense (sensu stricto), and 11.5\% (72/621) had lice from the Haematopinus tuberculatus species. Six animals presented mixed infestations of ticks and lice. Among the sampled farms, 51.6\% (31/60) had at least one animal infested with ectoparasites. The prevalence of ticks and lice on buffaloes was associated with the farm site, with higher prevalence (11.5\% ticks, $15.4 \%$ lice) in animals at dry land (OR: 16.7 and 5.7 for ticks and lice, respectively) when compared with floodplains (0.5\% ticks, 3.4\% lice). Buffaloes aged 1 to 12 months had more ticks whereas buffaloes aged 13 to 24 months had more lice $(P<0.05)$.

Conclusions: Buffaloes bred in the municipality of Santarém present different levels of tick and lice infestation according to the direct influence of Amazon ecosystem characteristics. The floodplain environment, widely used for buffalo farming, contributes toward minor ectoparasite infestations in these animals.
\end{abstract}

Keywords: Amazon ecosystem, Bubalus bubalis, Buffalo, Ectoparasite, Lice, Tick

\section{Background}

There are 1.78 million buffaloes in Brazil, of which 507,000 (38\%) are found in Pará state, northern region of Brazil [1]. In Santarém, and throughout the western region of the state, buffaloes are raised either on dry land (regular farms) or/and inhabit floodplain ecosystems through 6-8 months of the year, when the rivers

\footnotetext{
* Correspondence: ah.minervino@gmail.com

${ }^{1}$ Laboratório de Sanidade Animal, Universidade Federal do Oeste do Pará, LARSANA/UFOPA, Rua Vera Paz, s/n, CEP 68100-000 Santarém, Pará, Brasil Full list of author information is available at the end of the article
}

are drying out and pastures become available. This floodplain production system is extensive and characterized by minimal animal management [2].

Buffaloes are known for being resistant to tick infestations. However, some tick species parasitize buffaloes, although usually at a lower intensity than in cattle [3]. The tick species Rhipicephalus (Boophilus) microplus and Amblyomma cajennense complex typically parasitize buffaloes [4-6].

There have been few reports about tick parasitism in buffaloes in Brazil. In the states of São Paulo and Minas Gerais, southeastern region, a natural infestation of $R$. (B) microplus and Dermacentor nitens was reported in

(C) The Author(s). 2018 Open Access This article is distributed under the terms of the Creative Commons Attribution 4.0 International License (http://creativecommons.org/licenses/by/4.0/), which permits unrestricted use, distribution, and 
buffaloes, the ticks mainly parasitizing the groin and axilla, perineum, udder and other regions where the skin is thinner and the hair shorter [4]. In Rio de Janeiro, also in the southeastern region of Brazil, $82.3 \%$ of buffalo herds show tick infestations; nonetheless, other ectoparasites have not been considered in previous studies in this region [7]. Amblyomma sculptum, the vector of Brazilian spotted fever, which has low host parasitic specificity, has previously been found in buffaloes [8].

Among the species of ectoparasites that affect buffaloes, Haematopinus tuberculatus lice are specific to buffaloes, and thus the main ectoparasite of the species [8, 9]. In Brazil, Silva et al. [10] suggest that $H$. tuberculatus may be involved in transmission of diseases, such as anaplasmosis.

Very little is known about the risk factors related to the presence of ticks or lice in buffaloes, especially in the Amazon region, which presents a unique farming system that strongly utilizes floodplains. This study aimed to identify the species of ectoparasites in buffaloes in the municipality of Santarém, Pará, and to determine the possible risk factors related to parasitic infestation.

\section{Methods}

\section{Study area}

This study was carried out in the municipality of Santarém, in the western region of the state of Pará, northern Brazil, and included properties located in dry areas (conventional properties) and in floodplain areas; the latter are extensively found along the banks of the Amazon River and are inundated annually. In addition, during the drought period, these areas provide natural pastures that are used for livestock activities; animals are transported to the floodplains where they remain for up to 8 months of the year, only returning to the dry areas during the peak flood of the Amazon River [11]. The buffalo herd in this municipality consists of approximately 8,364 buffaloes, distributed across 232 properties [1]. Figure 1 presents the studied area.

\section{Experimental design}

A cross-sectional study was carried out with a two-stage sampling procedure. The first stage included sampling of rural properties. Sample size calculation was performed with the software Epi Info (CDC), using the following data: population size: 232 farms; frequency of expected

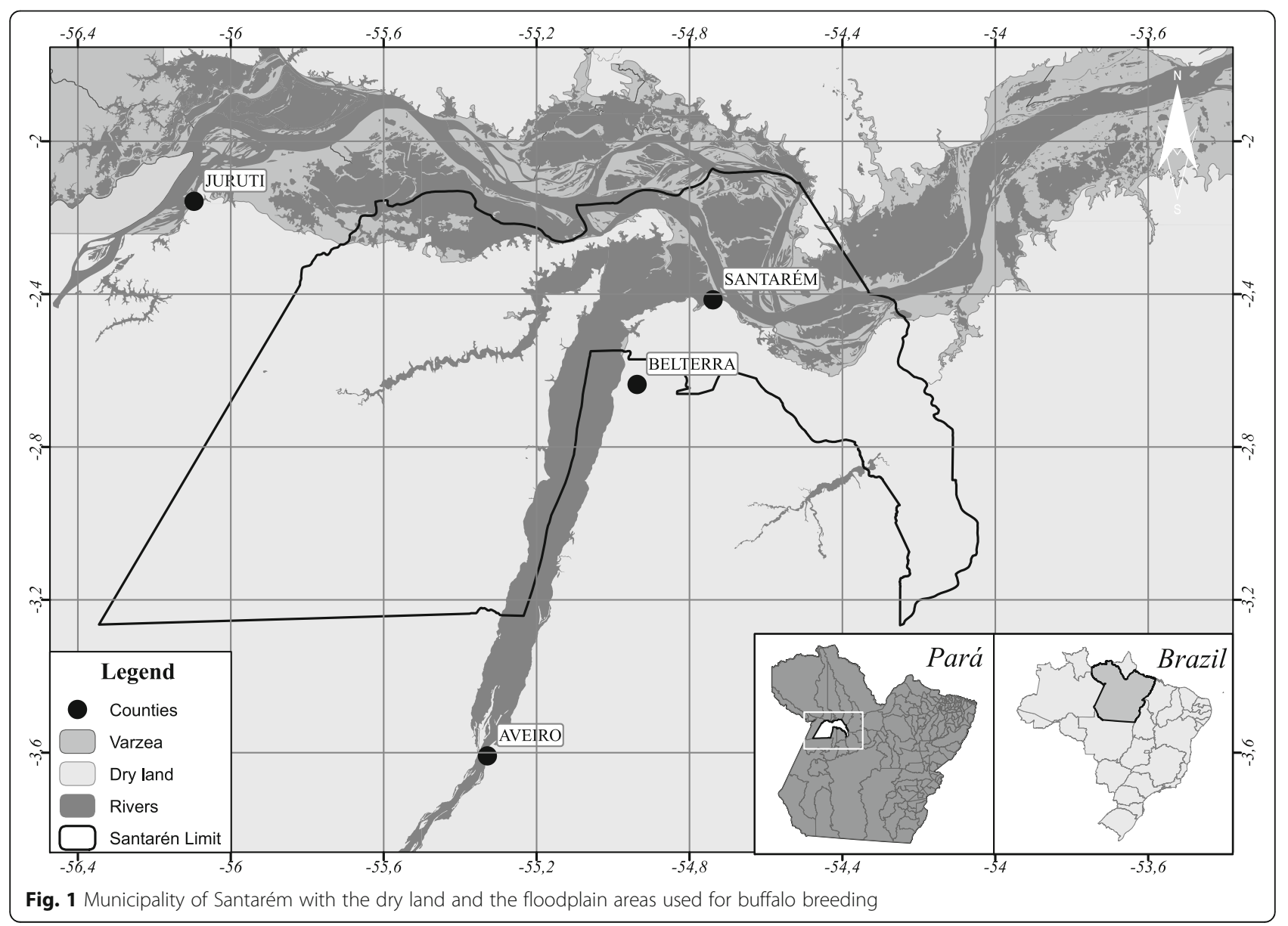


tick infestation (farm-level): 82\% [7]; confidence level: 95\%; confidence limits: $8.4 \%$. Accordingly, we calculated that 60 farms (clusters) needed to be sampled, representing $25.9 \%$ of the total number of properties on which buffaloes were raised in the municipality. To select the farms, a systematic sampling approach was adopted from the list of producers registered at the Agency of Agricultural Defense of the State of Pará in the year of 2015 .

The second sampling stage matched the number of animals collected from each rural property, calculated on site considering the total number of buffaloes in the farm according to a statistical formula for disease detection [12], assuming the following values: $95 \%$ confidence level; expected prevalence of ticks on buffaloes of $15 \%$ [4]; test sensitivity of $95 \%$.

When the farms were visited to collect samples, an epidemiological questionnaire was used to obtain information related to farm location (dry land or floodplains), herd size, type of herd (beef or dairy), type of pasture, type of grazing, presence of mixed overgrowth pasture (presence of undesired plants such as bushes and shrubs in the pasture), pasture resting, control of ectoparasites (if any), and presence of wild animals. Individual details of each animal such as sex, age, breed, type (beef or dairy) and origin (born at farm or bought) were obtained. We also checked if the buffaloes were maintained with other animal species, and if they were transported to floodplains.

\section{Ectoparasite collection}

After appropriate containment, the buffaloes were examined in predefined body areas (neck, ears, back and tip of the tail), and the ectoparasites found were collected from each animal, particularly ticks and lice. The collected ectoparasites were placed into plastic tubes containing absolute alcohol, and were subsequently morphologically identified through specific characteristics [13-15].

\section{Statistical analysis}

Two distinct buffalo conditions were considered for statistical data analyses: presence/absence of ticks and presence/absence of lice. Thus, univariate analysis was performed by Chi-square or Fisher's exact test (less than five observations in at least one cell in the contingency table) to investigate the association of ticks or lice and possible risk factors obtained through an epidemiological questionnaire. Subsequently, a multivariate model was built by including every hypothesized risk factor which had a $P$-value $<0.200$ from the univariate analysis. A logit binary logistic regression with a hierarchic backward stepwise elimination method was used with the lowest risk category was taken as the baseline. Variables were retained if the $P$-value from the logistic regression was $<0.05$, otherwise they were removed from the final model. Model validity and reliability was assessed using the Hosmer-Lemeshow goodness-of-fit test [16]. Analyses were performed at two levels: (i) individual animal-level, which considered the prevalence among the entire population sampled, and (ii) herd-level, which evaluated the prevalence across all farms sampled. Each farm was considered a sampling unit, which could be positive (when at least one animal on the property was infested with ticks or lice) or negative (when no animal on the property was infested with ticks or lice).

Statistical analyses were performed using Minitab 17 software (Minitab Inc., State College, USA). Differences were considered significant when $P$-values were $\leq 0.05$.

Prevalence and abundance rates, along with mean infestation intensity and mean crowding were calculated, with respective 95\% CIs, in accordance with the report by Bush et al. [17], using the Quantitative Parasitology 3.0 software [18]. In this study, prevalence refers to the number of infested buffaloes/number of examined buffaloes $\times 100$. Mean abundance refers to the total number of ticks collected/total number of buffaloes analyzed. Mean intensity refers to the total number of ticks collected/number of infested buffaloes. Mean crowding refers to the degree of species-specific ectoparasite interactions observed on the same host.

\section{Results}

\section{General characteristics}

Sixty farms and 621 buffaloes were sampled. Of these, 34 (56.6\%) farms were located on dry land areas, and 26 (43.3\%) on floodplain areas. Two farms (3.3\%) were considered medium-sized herds (101-500 animals), 24 (40\%) were considered small herds (16-100 animals), and $34(56.6 \%)$ were considered micro herds (1-15 animals). Of the 621 animals, $385(62.0 \%)$ were female and $236(38.0 \%)$ were male, 153 (24.6\%) were calves ( 1 to 12 months), 222 (35.7\%) were heifers (12 to 24 months) and 246 (39.6\%) were adults (over 24 months). The animals were raised for beef $(229,36.9 \%)$ and for dairy (392, 63.1\%). They belonged to the following breeds: Jafarabadi, 1 (0.16\%); Mediterranean, 96 (15.4\%); Murrah, 88 (14.1\%); and crossbreeds, 436 (70\%). From the total sampled 70 (11.2\%) were purchased from other farms, and 551 (88.7\%) were born at the properties.

Nineteen farms (31\%) had cultivated pastures, 36 (60\%) farms had native pasture and five (8.33\%) farms had mixed pasture (native and cultivated). In terms of grazing management, 42 farms (70\%) used the continuous system, $14(23 \%)$ used the alternating system and four (7\%) used the rotational system. Mixed overgrowth pastures were present in most of the farms (55/60). Of the 
farms visited $60 \%(36 / 60)$ controlled ectoparasites (spraying and injectable antiparasitic drugs). Most of the farms (55/60) moved part of their buffalo herd to floodplain areas during a period of the year.

\section{Prevalence of ectoparasites}

Of the 60 sampled properties, 31 (51.6\%) contained animals with ectoparasites (lice and ticks); of the 621 buffaloes sampled, 115 (18.5\%) had ectoparasites, with 49 animals $(7.9 \%)$ parasitized by ticks, $72(11.6 \%)$ parasitized by lice (H. tuberculatus) and six parasitized by both ticks and lice.

A total of 95 ticks were found, including 1 larva, 1 nymph and 93 adults. The nymph and adults were all identified at the species level. The nymph and 48 adults (9 males, 38 females) belonged to $R$. (B.) microplus, while the other 45 adults (22 males, 23 females) belonged to Amblyomma cajennense (sensu stricto). The larva was identified as belonging to the genus Amblyomma. Five of the tick-parasitized animals presented mixed infestation by the two species of ticks identified. Table 1 shows the number, sex and life-cycle stage of the ectoparasites found on the buffaloes.

Among the two tick species, the most frequently found was $R$. (B.) microplus, which infested 26 buffaloes, while $A$. cajennense (sensu stricto) infested 23 animals. Considering the occurrence of ticks per animals, 23 buffaloes were infested by 1 adult tick, 23 were infested by $2-4$ adult ticks, and 3 animals were infested by 5 or more ticks. Regarding the $R$. (B.) microplus species, 13 buffaloes were infected by 1 tick, and 12 buffaloes were infected by 2-4 ticks. Regarding the $A$. cajennense (sensu stricto), 10 buffaloes were infected by 1 tick, 11 animals were infected by 2 to 4 ticks, and 2 animals were infected by 5 ticks. Table 2 presents the prevalence, mean intensity, mean abundance, mean crowding, and their respective 95\% CI values of tick infestation on the parasitized buffaloes.

We do not present information on the number of lice per animal as, depending on the collection conditions, the number of individuals collected may differ from the

Table 1 Total number, life-cycle stage and species of ectoparasites identified on buffaloes on 60 farms

\begin{tabular}{|c|c|c|c|c|c|}
\hline \multirow[t]{2}{*}{ Ectoparasite } & \multirow[t]{2}{*}{ Larva $^{a}$} & \multirow[t]{2}{*}{ Nymph $^{a}$} & \multicolumn{2}{|c|}{ Adult $^{a}$} & \multirow[t]{2}{*}{ Total } \\
\hline & & & Male & Female & \\
\hline \multicolumn{6}{|l|}{ Ticks } \\
\hline $\begin{array}{l}\text { Rhipicephalus (Boophilus) } \\
\text { microplus }\end{array}$ & - & $1 / 1$ & $9 / 6$ & $39 / 19$ & $49 / 26$ \\
\hline Amblyomma sp. & $1 / 1$ & - & $22 / 9$ & $23 / 13$ & $46 / 23$ \\
\hline \multicolumn{6}{|l|}{ Lice } \\
\hline Haematopinus tuberculatus & - & - & \multicolumn{2}{|c|}{$320 / 72$} & $320 / 72$ \\
\hline
\end{tabular}

total number of ectoparasites present on the animal. However, all collected lice were of the $H$. tuberculatus species, and were at the adult stage of their life-cycle.

Analysis of risk factors for the presence of ticks and lice The prevalence of ticks and lice on farms (herd-level) was $31.6 \%(19 / 60)$ and $33.3 \%(20 / 60)$, respectively. Table 3 shows the results of the univariate analysis of risk factors related to the presence of ticks and lice on the farms. Regarding tick infestation at the herd-level, the logistic regression model resulted in the farm site detected as the only significative risk factor, with farms located on dry land being more infested by ticks (OR $=25$, 95\% CI: 3.0-205.9, $P=0.001$ ) than farms on the floodplain. The logistic regression for lice infestation at the herd-level (data not shown) had a significant result $(P=0.038)$ for the Hosmer-Lemeshow goodness-of-fit test, thus the model does not fit with the data and the predicted probabilities deviate from the observed probabilities in a way that the binomial distribution does not predict.

Of the 621 buffaloes evaluated, 49 (7.8\%) were infested by ticks and $72(11.5 \%)$ were infested by lice. Table 4 shows the risk factors linked to the presence of ectoparasites in the buffaloes (individual animal-level). Murrah (ticks: 6/88, 6.8\%; lice: 12/88, 13.6\%), Mediterranean (ticks: 4/96, 4.2\%; lice: 1/96, 1.0\%) and crossbreed animals (ticks: 39/436, 8.9\%; lice: 59/436, 13.5\%) were infested by ticks and lice. The single Jafarabadi buffalo examined had no ticks or lice. There was no association between buffalo breed and the prevalence of ticks or lice.

The binary logistic regression model of tick and lice infestation at the individual animal-level is presented in Table 5. The factors age, farm site and origin of animal were associated with a higher infestation of ticks in the multivariate analysis. Animals raised on dry land are 16.7 times more likely to be infested by ticks than buffalo raised at floodplains (95\% CI: $2.3-123.3 ; P=0.006$ ). Animals aged 1-12 months were six times more likely to be infested with ticks than those aged $>24$ months (95\% CI: 2.5-14.5; $P=0.0001$ ) and buffaloes bought from other farms were more likely to be infested by ticks than animals born on farm (OR: 3.6; 95\% CI: 1.4-9.2; $P=0.007)$. For lice, age and farm site were retained in the final model and related with a higher infestation. Buffalo aged 13-24 months had more lice than young animals (1-12 m) (OR: 3.8; 95\% CI: 1.8-8.0; $P=0.001)$. Similarly as tick infestation, buffalo raised on dry land are more likely to have lice than animals at floodplains (OR: 5.7; 95\% CI: 2.6-12.8; $P=0.001)$.

\section{Discussion}

In the present study, $7.9 \%$ of all examined animals had ticks, which is lower than the prevalence rates found in 
Table 2 Prevalence, intensity, abundance and crowding of tick infested buffaloes in Santarém, Pará, Brazil

\begin{tabular}{lllll}
\hline Tick & $\begin{array}{l}\text { Prevalence }(\%)^{a} \\
(95 \% \mathrm{Cl})\end{array}$ & $\begin{array}{l}\text { Mean intensity } \\
(95 \% \mathrm{Cl})\end{array}$ & $\begin{array}{l}\text { Mean abundance }^{\mathrm{c}} \\
(95 \% \mathrm{Cl})\end{array}$ & $\begin{array}{l}\text { Mean }^{\mathrm{c}} \mathrm{crowding}^{\mathrm{d}} \\
(95 \% \mathrm{Cl})\end{array}$ \\
\hline Rhipicephalus (Boophilus) microplus & 4.03 & 2.00 & 0.08 & 2.60 \\
& $(2.62-5.89)$ & $(1.56-2.40)$ & $(0.05-0.11)$ & $(2.14-3.07)$ \\
Amblyomma cajennense (sensu stricto) & 3.70 & 2.00 & 0.07 & 2.74 \\
& $(2.36-5.51)$ & $(1.52-2.57)$ & $(0.05-0.11)$ & $(2.06-3.59)$ \\
\hline
\end{tabular}

${ }^{\mathrm{a}}$ The number of infested buffaloes/number of examined buffaloes $\times 100$

${ }^{b}$ Total number of collected ticks/number of infested buffaloes

'Total number of collected ticks/total number of analyzed buffaloes

${ }^{\mathrm{d}}$ The degree of interaction of a parasite with individuals of the same species in the same host

Abbreviation: $\mathrm{Cl}$, confidence interval

Table 3 Univariate analysis of risk factors related to the presence of ticks and lice at the farm-level in the municipality of Santarém, Brazil

\begin{tabular}{|c|c|c|c|c|c|c|}
\hline \multirow[t]{2}{*}{ Risk factor } & \multicolumn{3}{|l|}{ Ticks } & \multicolumn{3}{|l|}{ Lice } \\
\hline & Positive/total (\%) & $P^{a}$ & OR $(95 \% \mathrm{Cl})$ & Positive/total (\%) & $P^{a}$ & OR $(95 \% \mathrm{Cl})$ \\
\hline Farm location & & $<0.001$ & $24.00(2.91-198.10)$ & & 0.002 & $7.66(1.93-30.43)$ \\
\hline Dry land & $17 / 34(50.0)$ & & & $17 / 34(50.0)$ & & \\
\hline Floodplain & $1 / 26(3.85)$ & & & $3 / 26(11.5)$ & & \\
\hline Herd size & & na & na & & na & na \\
\hline Medium & $0 / 2(0.0)$ & & & $1 / 2(50.0)$ & & \\
\hline Micro & 6/34 (17.6) & & & 6/34 (17.6) & & \\
\hline Small & $12 / 24(54.1)$ & & & $13 / 24(54.1)$ & & \\
\hline Animals go to floodplain area & & 0.003 & $0.25(0.03-1.64)$ & & 0.741 & $0.72(0.11-4.76)$ \\
\hline Yes & $15 / 55(27.2)$ & & & 18/55 (32.7) & & \\
\hline No & $3 / 5(60.0)$ & & & $2 / 5(40.0)$ & & \\
\hline Type of pasture & & 0.019 & b & & 0.066 & na \\
\hline Cultivated & 9/19 (47.3) & & & 6/19 (31.5) & & \\
\hline Mixed & $3 / 5(60.0)$ & & & $4 / 5(80.0)$ & & \\
\hline Native & 6/36 (16.6) & & & $10 / 36(27.7)$ & & \\
\hline Type of grazing & & 0.001 & c & & 0.097 & na \\
\hline Alternating & $9 / 14(64.2)$ & & & $8 / 14(57.1)$ & & \\
\hline Continuous & 5/42 (11.9) & & & $11 / 42(26.1)$ & & \\
\hline Rotational & 4/4 (100.0) & & & $1 / 4(25.0)$ & & \\
\hline Mixed overgrowth pastures & & 0.126 & $0.27(0.04-1.79)$ & & 0.509 & $2.11(0.22-20.26)$ \\
\hline Yes & $15 / 55(27.7)$ & & & 19/55 (34.5) & & \\
\hline No & $3 / 5(60.0)$ & & & $1 / 5(20.0)$ & & \\
\hline Control ectoparasites & & 0.066 & $2.41(0.73-7.96)$ & & $<0.001$ & $11.00(2.24-53.86)$ \\
\hline Yes & 14/36 (38.8) & & & 18/36 (50.0) & & \\
\hline No & 4/24 (16.6) & & & 2/24 (8.3) & & \\
\hline Presence of wild animals & & 0.907 & $0.91(0.20-4.12)$ & & 0.443 & $0.57(0.13-2.41)$ \\
\hline Yes & 15/51 (31.3) & & & 16/51 (31.3) & & \\
\hline No & 3/9 (33.3) & & & 4/9 (44.4) & & \\
\hline
\end{tabular}

${ }^{a}$ Calculated using Chi-square or Fisher's tests

${ }^{\text {b}}$ Type of pasture: cultivated vs mixed (OR: 0.60, $P=1.00$ ); cultivated vs native (OR: 4.50, $P=0.015$ ); mixed vs native (OR: 7.50, $P=0.06$ )

'Type of grazing: alternating vs continuous (OR: 13.32, $P<0.0001)$; alternating vs rotational (OR: $0.19, P=0.278)$; continuous vs rotational $(\mathrm{OR}: 0.02, P=0.0008)$

Notes: A farm was considered positive when at least 1 of the examined animals was infested with lice or ticks. Herd size: micro (1-15 animals); small (16-100 animals); medium (101-500 animals). Mixed overgrowth is the presence of undesired plants such as bushes and shrubs in the pasture Abbreviations: $\mathrm{OR}$, odds ratio; $\mathrm{Cl}$, confidence interval; na, not available. 
Table 4 Univariate analysis of risk factors related to infestations of buffaloes by ticks and lice (individual animal-level) in the municipality of Santarém, Amazon region, Brazil

\begin{tabular}{|c|c|c|c|c|c|c|}
\hline \multirow[t]{2}{*}{ Risk factor } & \multicolumn{3}{|l|}{ Ticks } & \multicolumn{3}{|l|}{ Lice } \\
\hline & Positive/total (\%) & $P^{a}$ & OR $(95 \% \mathrm{Cl})$ & Positive/total (\%) & $P^{a}$ & OR $(95 \% \mathrm{Cl})$ \\
\hline Sex & & 0.908 & $1.03(0.56-1.88)$ & & 0.260 & $0.74(0.43-1.20)$ \\
\hline Male & 19/236 (8.0) & & & 49/385 (12.7) & & \\
\hline Female & 30/385 (7.7) & & & 23/236 (9.7) & & \\
\hline Age (months) & & $<0.001$ & b & & 0.002 & d \\
\hline $1-12$ & 29/153 (18.9) & & & $10 / 153(6.5)$ & & \\
\hline $13-24$ & $10 / 222(4.5)$ & & & $39 / 222(17.5)$ & & \\
\hline$>24$ & $10 / 246(4.0)$ & & & 23/246 (9.3) & & \\
\hline Type & & 0.209 & $1.50(0.79-2.86)$ & & 0.149 & $1.48(0.86-2.53)$ \\
\hline Dairy & 35/392 (8.9) & & & $21 / 229(9.1)$ & & \\
\hline Beef & $14 / 229(6.1)$ & & & $51 / 392(13.0)$ & & \\
\hline Herd size & & 0.006 & c & & 0.025 & e \\
\hline Micro & $12 / 218(5.5)$ & & & 17/218 (7.8) & & \\
\hline Small & $37 / 347(10.6)$ & & & $51 / 347(14.7)$ & & \\
\hline Medium & $0 / 56(0.0)$ & & & $4 / 56(7.1)$ & & \\
\hline Farm site & & $<0.001$ & $25.81(3.53-188.50)$ & & $<0.001$ & $5.07(2.28-11.29)$ \\
\hline Dry land & $48 / 420(11.5)$ & & & $65 / 420(15.4)$ & & \\
\hline Floodplain & $1 / 201(0.5)$ & & & $7 / 201(3.4)$ & & \\
\hline Origin & & 0.102 & $1.88(0.87-4.07)$ & & 0.020 & \\
\hline Bought & 9/70 (12.8) & & & 14/70 (20.0) & & \\
\hline Born on farm & 40/551 (7.2) & & & $58 / 551(10.5)$ & & \\
\hline Maintained with other animals & & 0.010 & $0.46(0.25-0.84)$ & & 0.249 & $1.38(0.79-2.40)$ \\
\hline Yes & 25/420 (5.9) & & & $53 / 420(12.6)$ & & \\
\hline No & 24/201 (11.9) & & & 19/201 (9.4) & & \\
\hline
\end{tabular}

${ }^{a}$ Calculated using Chi-square or Fisher's tests

${ }^{b}$ Age (months): $1-12$ vs 13-24 months (OR: 4.96, $\left.P=0.001\right) ; 1-12$ vs $>24$ months (OR: $\left.5.52, P=0.001\right) ; 13-24$ vs $>24$ months (OR: $\left.1.11, P=0.814\right)$

'Herd size: micro vs small (OR: $0.49, P=0.033)$; micro vs medium (OR: $6.84, P=0.134)$; small vs medium $(\mathrm{OR}: 13.65, P=0.005)$

${ }^{\mathrm{d}}$ Age (months): $1-12$ vs 13-24 months (OR: 0.33, $\left.P=0.002\right) ; 1-12$ vs $>24$ months (OR: $\left.0.68, P=0.321\right) ; 13-24$ vs $>24$ months (OR: $\left.2.07, P=0.009\right)$

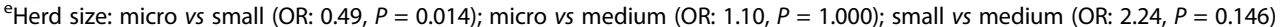

Abbreviations: $\mathrm{OR}$, odds ratio; $\mathrm{Cl}$, confidence interval

Note: Herd size: micro (1-15 animals); small (16-100 animals); medium (101-500 animals)

Pakistan (52.5\% [19]), Cuba (27.7\%) [20] and India (56.7\%) [21]. The prevalence of ticks at the herd-level was $31.6 \%$, which was less than the $82.3 \%$ prevalence rate found in Rio de Janeiro farms [7]. Buffaloes raised in the Santarém region were infested by two tick species, $R$. (B.) microplus and A. cajennense (sensu stricto), both of which have already been identified as parasites typically found in buffaloes $[8,22]$.

Of the 60 sampled farms, $33.3 \%$ harbored animals infested by $H$. tuberculatus lice, indicative of the prominence of this parasite in bubaline species and their presence in the farms in this region. Regarding the prevalence of infested animals with lice our prevalence rate of $11.6 \%$ was close to the infestations rates found in Italy [23] and Pakistan [24].

Of the two tick species identified, the $R$. (B.) microplus and $A$. cajennense (sensu stricto) presented similar prevalence, intensity, abundance and mean crowding. In Minas Gerais State, Brazil, the prevalence of $R$. (B.) microplus ticks in buffaloes ranges between 15.4-38.5\% throughout the year [4]. Considering the lack of data from buffaloes, our results from tick abundancy, intensity and crowding are hard to discuss, and more studies need to be done with evaluation of infestation in different seasons. It is important for report that the samples were obtained during the dry season, the period when it is possible to raise buffalos in floodplain areas since during the wet season the fields are flooded [2].

The univariate analysis at the herd-level demonstrated an association of tick infestation with different risk factors (type of pasture, type of grazing, etc.), but only the farm site was retained in the final logistic regression model, indicating that other risk factors were associated with the main effect of farm site. Farms on dry land had 
Table 5 Logit binary logistic regression of tick and lice infestation in buffaloes in the municipality of Santarém, Amazon region, Brazil

\begin{tabular}{|c|c|c|c|c|c|c|}
\hline \multirow[t]{2}{*}{ Variable $^{a}$} & \multicolumn{3}{|l|}{ Ticks } & \multicolumn{3}{|l|}{ Lice } \\
\hline & $\overline{\mathrm{OR}}$ & $95 \% \mathrm{Cl}$ & $p^{\mathrm{b}}$ & $\overline{\mathrm{OR}}$ & $95 \% \mathrm{Cl}$ & $p^{\mathrm{b}}$ \\
\hline \multicolumn{7}{|l|}{ Age (months) } \\
\hline 1 to 12 & 5.99 & $2.48-14.51$ & 0.001 & Baseline & & \\
\hline 13 to 24 & 1.05 & $0.42-2.64$ & 0.922 & 3.83 & $1.83-8.01$ & 0.001 \\
\hline$>24$ & Baseline & & & 2.07 & $0.95-4.53$ & 0.069 \\
\hline \multicolumn{7}{|l|}{ Farm site } \\
\hline Dry land & 16.68 & $2.26-123.27$ & 0.006 & 5.72 & $2.55-12.83$ & 0.001 \\
\hline Floodplain & Baseline & & & Baseline & & \\
\hline \multicolumn{7}{|l|}{ Origin } \\
\hline Bought & 3.61 & $1.42-9.15$ & 0.007 & - & - & \\
\hline Born on farm & Baseline & & & - & - & \\
\hline
\end{tabular}

${ }^{a}$ Only factors that remained significantly associated in the final model $(P<0.05)$ are included

${ }^{b}$ Logit binary regression analysis with Backward stepwise elimination in a hierarchic model. Hosmer-Lemeshow goodness-of-fit test: $P=0.233$ (ticks), $P=0.480$ (lice)

Abbreviations: $\mathrm{OR}$, odds ratio; $\mathrm{Cl}$, confidence interval

animals with more ticks and this difference could be explained by the biological cycle of ticks, which may be interrupted when flooding occurs between February and June. The periodic flooding of grazing area and the constant movement of animals to reach newly unflooded areas during the ebb period (e.g. the period when the river is drying), are both factors that may reduce the tick population in the environment and animal infestation [25].

At the individual animal-level, the multivariate analysis of tick infestations included in the final model the follow risk factors: farm site, age and origin of animals. Young buffaloes were more susceptible to tick infestation, consistent with previous literature data [19]. In our study, animals aged between 1 and 12 months were six times more likely to be infested with ticks than those aged $>24$ months. Sex, breed and aptitude were not associated with tick infestation in buffaloes. Similarly to the herd-level analysis, the animals raised in floodplains had lower tick infestation. Previous research in India demonstrated that animals brought for grazing on pasture lowlands had lower mature tick populations when compared with stall-fed buffaloes on dairy farms and this occurred supposedly because of predation of ticks by birds in the field [26].

Considering the origin of animals (born on property or bought from other farms) the buffaloes that were bought from other farms were more likely to be infested by ticks. This was probably due to the source of animals, usually bought from dry land for the purpose of reproduction [2].

The univariate analysis of lice infestation at the herd-level indicated association with several risk factors (age, herd size, origin), but the multivariate analysis for lice infestation at the herd-level presented a model that does not fit to the data, probably due to a limited amount of data ( $n=60$ farms) and similarity of results; these data are, therefore, not shown.

The multivariate analysis of lice infestations at the individual animal-level included only age and farm site in the final model. Dry land animals were 5.7 times more likely to be infested with lice than floodplain animals, which might be explained by the biological cycle of $H$. tuberculatus, which is completed within the host body. Moreover, maintenance of the parasite on the body of floodplain animals may be impaired by the daily periods spent in the water, searching for food. The parasites are found in greater concentrations around the ears, base of horns, side of the neck, around the scrotum or udder, and especially at the tip of the tail $[15,27]$. Some of these areas would be submerged during water grazing or movement of the buffaloes in floodplain areas.

In this study, animals aged over 12 months had a greater prevalence of lice than young animals (aged 1-12 months). Studies indicate that young buffaloes are more susceptible to infestation by $H$. tuberculatus [28]. Our results may be related to the grazing habits of buffaloes in floodplain areas, where part of the body remains submerged during grazing and movement across pastures. Given that younger animals are smaller, a more substantial proportion of the body would be submerged while accompanying adult animals, possibly explaining the lower prevalence of lice in younger animals observed in our study.

Despite presenting significant results of the univariate analysis the risk factors herd size and origin of animal were not significant in the multivariate analysis and 
removed by backward stepwise elimination from the final regression model. For lice, only age and farm site were associated with the parasite infestation.

The ticks and the lice founded in buffaloes have been previously related as vectors of important pathogens such Babesia sp. and Anaplasma marginale [10, 29, 30], but limited information is available regarding piroplasmosis in cattle from Santarém and nearby municipalities. Thus, further studies are required to investigate whether buffaloes act as a significant reservoir of tick species and also the role of buffaloes in the epidemiology of piroplasmosis in ruminants in the region.

Buffaloes bred in the municipality of Santarém presented different levels of infestation by ticks and lice, which was mainly influenced by the unique characteristics of the Amazon ecosystem. The floodplain environment, widely used for buffalo farming, contributes to the minor infestation rates by ectoparasites in these animals.

\section{Conclusions}

Buffaloes bred in the municipality of Santarém present different levels of tick and lice infestation according to the direct influence of Amazon ecosystem characteristics. The floodplain environment, widely used for buffalo farming, contributes toward minor ectoparasite infestations in these animals.

\section{Abbreviation}

$\mathrm{Cl}$ : confidence interval

\section{Acknowledgements}

We thank the CNPq for the research productivity fellowship granted to Antonio Humberto Hamad Minervino, Solange Maria Gennari and Arlei Marcili. The authors are grateful to Dr Marcelo Bahia Labruna for his support during this study.

\section{Funding}

This research was funded by National Council for Scientific and

Technological Development - CNPq, Brazil (Grant \# 486318/2013-3).

\section{Availability of data and materials}

The data supporting the conclusions of this article are included within the article.

\section{Authors' contributions}

AHHM, SMG and AM designed the study and obtained funding. HRB, DRO, CS and ACM participated in the execution of the experiment. HRB and CS performed tick identification. AHHM, SMG, LESB and FNB wrote the manuscript. All authors read and approved the final manuscript.

\section{Ethics approval}

This study was approved by the Animal Use Committee from the Federal University of Western Pará (Authorization \#04008/2015).

\section{Consent for publication}

Not applicable.

\section{Competing interests}

The authors declare that they have no competing interests.

\section{Publisher's Note}

Springer Nature remains neutral with regard to jurisdictional claims in published maps and institutional affiliations.

\section{Author details}

'Laboratório de Sanidade Animal, Universidade Federal do Oeste do Pará LARSANA/UFOPA, Rua Vera Paz, s/n, CEP 68100-000 Santarém, Pará, Brasil. ${ }^{2}$ Faculdade de Medicina Veterinária e Zootecnia, Universidade de São Paulo, FMVZ/USP, Av. Prof. Orlando Marques de Paiva 87, Cidade Universitária, São Paulo, SP 05508-270, Brazil. ${ }^{3}$ Mestrado em Medicina e Bem estar animal, Universidade Santo Amaro, Av. Prof. Eneas de Siqueira Neto, 340, São Paulo 04529-300, Brazil. ${ }^{4}$ Programa de Pós-Graduação em Recursos Naturais da Amazônia, Universidade Federal do Oeste do Pará, PGRNA/UFOPA, Av. Mendonça Furtado 2240, CEP 68100-000 Santarém, Pará, Brasil.

Received: 5 February 2018 Accepted: 25 May 2018

Published online: 04 June 2018

\section{References}

1. IBGE. Produção da pecuária municipal. 47th ed. 2015. http://biblioteca.ibge.gov. br/visualizacao/periodicos/84/ppm_2015_v43_br.pdf. Accessed 18 Oct 2016.

2. Vale WG, Minervino AHH, Neves KAL, Morini AC, Coelho JAS. Buffalo under threat in Amazon Valley, Brazil. Buffalo Bull. 2013;32:121-31.

3. Nithikathkul C, Polseela P, Changsap B, Leemingsawat S. Ixodid ticks on domestic animals in Samut Prakan Province, Thailand. Southeast Asian J Trop Med Public Health. 2002;33:41-4.

4. Rocha U, Serra O, Grock R, Serra R. Natural buffalo infestation from the states of São Paulo and Minas Gerais, Brazil, by Boophilus microplus (Canestrini, 1997) and by Anocentor nitens (Neumann, 1897), Acari, Ixodidae. Arq Inst Biol (Sao Paulo). 1969:36:197-9.

5. Nava S, Beati L, Labruna MB, Cáceres AG, Mangold AJ, Guglielmone AA. Reassessment of the taxonomic status of Amblyomma cajennense (Fabricius, 1787) with the description of three new species, Amblyomma tonelliae n. sp., Amblyomma interandinum n. sp. and Amblyomma patinoi n. sp., and reinstatement of Amblyomma mixtum Koch, 1844, and Amblyomma sculptum Berlese, 1888 (Ixodida: Ixodidae). Ticks Tick Borne Dis. 2014;5:252-76.

6. Benitez D, Cetrá B, Florin-Christensen M. Rhipicephalus (Boophilus) microplus ticks can complete their life cycle on the water buffalo (Bubalus bubalis). J Buffalo Sci. 2012:1:193-7.

7. Corrêa FN, Cunha NC, Rangel CP, Fonseca AH. Ticks on buffaloes (Bubalus bubalis) in the state of Rio de Janeiro, Brazil. Brazilian J Vet Parasitol. 2012;21:313-4

8. Bastianetto $\mathrm{E}$, Leite RC. Aspectos epidemiológicos e controle das doenças parasitárias em bubalinos. Ciência Anim Bras. 2009;10:1-17.

9. Veneziano V, Santaniello M, Carbone S, Pennacchio S, Morgoglione ME, Schioppi M, et al. Lice (Haematopinus tuberculatus) in water buffalo farms from central Italy. Ital J Anim Sci. 2007;6:926-7.

10. Da Silva AS, Lopes LS, Diaz JDS, Tonin AA, Stefani LM, Araújo DN. Lice outbreak in buffaloes: evidence of Anaplasma marginale transmission by sucking lice Haematopinus tuberculatus. J Parasitol. 2013;99:546-7.

11. Minervino $\mathrm{AHH}$, Cardoso C, Ortolani EL. Características do sistema produtivo da pecuária no município de Santarém, Pará. Acta Amaz. 2008:38:11-6.

12. Cannon RM, Roe RT. Livestock disease surveys. A field manual for veterinarians. Canberra: Australian Bureau of Animal Health, Department of Primary Industry, Australian Government Publishing Service; 1982.

13. Barros-Battesti D, Arzua M, Bechara H. Carrapatos de importância medicoveterinaria da região neotropical: Um guia ilustrado para identificação de especiés. São Paulo: Vox/ICTTD-3/Butantan; 2006.

14. Martins TF, Onofrio VC, Barros-Battesti DM, Labruna MB. Nymphs of the genus Amblyomma (Acari: Ixodidae) of Brazil: descriptions, redescriptions, and identification key. Ticks Tick Borne Dis. 2010;1:75-99.

15. Chaudhuri RP, Kumar P. The life history and habits of the buffalo louse, Haematopinus tuberculatus (Burmeister) Lucas. Indian J Vet Sci. 1961;31:275-325.

16. Hosmer DW, Lemeshow S. Applied logistic regression. Chicago: Wiley; 2000.

17. Bush AO, Lafferty KD, Lotz JM, Shostak AW. Parasitology meets ecology on its own terms: Margolis et al. revisited. J Parasitol. 1997;83:575.

18. Rózsa L, Reiczigel J, Majoros G. Quantifying parasites in samples of hosts. I Parasitol. 2000;86:228-32.

19. Tasawar Z, Nasim S, Lashari MH. The prevalence of ixodid ticks on buffaloes at private animal farm Bibipur, Multan. Glob Vet. 2014;12:154-7.

20. Obregon D, Rodriguez Diego JG, Roque E, Aleman Y. Rhipicephalus (Boophilus) microplus (Acari: Ixodidae) en búfalo (Bubalus bubalis), en Cuba. Rev Salud Anim. 2010;32:132-4.

21. Singh NK, Rath SS. Epidemiology of ixodid ticks in buffaloes (Bubalus bubalis) of Punjab, India. Buffalo Bull. 2018;35:347-53. 
22. Hussain Soomro M, Parveen Soomro S, Bachal Bhutto M, Akbar Z, Yaqoob M, Arijo AG. Prevalence of ticks in buffaloes in the upper Sindh Pakistan. Buffalo Bull. 2014;33:323-7.

23. Cringoli G, Musella V, Maurelli MP, Morgoglione ME, Santaniello A, Condoleo $R$, et al. Helminths and arthropoda in buffalo farms from the Lazio region (Italy). Vet Res Commun. 2009;33:129-31.

24. Kakar MN, Kakarsulemankhel JK. Prevalence of lice species on cows and buffaloes of Quetta, Pakistan. Pak Vet J. 2009;29:49-50.

25. Diamant G, Strickland RK. Manual on livestock ticks for Animal Disease Eradication Division personnel. USDA ARS. Washington: US Department of Agriculture, Agricultural Research Service; 1965.

26. Miranpuri GS. Ticks parasitising the Indian buffalo (Bubalus bubalis) and their possible role in disease transmission. Vet Parasitol. 1988;27:357-62.

27. Lau H. Piolho dos búfalos: biologia e controle. A Hora Veterinária. 1993;13:53-6.

28. Lau H, Costa N, Batista H. Infestação natural de piolhos em búfalos. Belém: Embrapa-Cpatu; 1980.

29. Obregón D, Oliveira MCS, Tizioto PC, Funnes ME, Martínez S, Roque E, et al. Diagnóstico de Babesia bovis en búfalos de la región occidental de Cuba a través de un ensayo de nPCR. Rev. Salud Anim. 2012;34:101-8.

30. Da Silva JB, André MR, da Fonseca AH, de Albuquerque Lopes $C T$, da Silva Lima DH, de Andrade SJT, et al. Molecular and serological prevalence of Babesia bovis and Babesia bigemina in water buffaloes in the north region of Brazil. Vet Parasitol. 2013;197:678-81.

Ready to submit your research? Choose BMC and benefit from:

- fast, convenient online submission

- thorough peer review by experienced researchers in your field

- rapid publication on acceptance

- support for research data, including large and complex data types

- gold Open Access which fosters wider collaboration and increased citations

- maximum visibility for your research: over $100 \mathrm{M}$ website views per year

At BMC, research is always in progress.

Learn more biomedcentral.com/submissions 